\title{
Effects of Predisposing, Enabling, and Reinforcing Factors on Completeness of Child Immunization in Pamekasan, Madura
}

\author{
Nur Jayanti'), Endang Sutisna Sulaeman²), Ety Poncorini Pamungkasari²) \\ 1)Masters Program in Public Health, Universitas Sebelas Maret \\ 2)Faculty of Medicine, Universitas Sebelas Maret
}

\begin{abstract}
Background: According to World Health Organization (WHO) Weekly Epidemiological Record, Indonesia ranked fourth the lowest country in immunization coverage after India, Nigeria, and Democratic Republic of Congo. Likewise, Pamekasan district in Madura was one of districs in East Java with the lowest immunization coverage. This study aimed to determine the effects of predisposing, enabling, and reinforcing factors on completeness of child immunization, using PRECEDE and PROCEED model, and health belief model.

Subjects and Method: This was an observational analytic study with case control design. This study was carried out at 4 community health centers in Pamekasan District, Madura, East Java, in March to April 2017. A sample of 135 mothers who had infants aged 10 to 12 months were selected for this study by fixed disease sampling. The dependent variable was completeness of immunization use. The independent variables were maternal education, attitude towards immunization, perceived susceptibility, perceived severity, perceived benefit, perceived barrier, self efficacy, family support, and distance to health service. The data were collected by questionnaire and analyzed using path analysis.

Results: Perceived barrier ( $b=-0.5 ; 95 \% \mathrm{CI}=-1.5$ to $0.4 ; \mathrm{p}=0.255)$ and distance to health service $(b=-1.0 ; 95 \% \mathrm{CI}=-2.0$ to $-0.1 ; \mathrm{p}=0.037)$ had a negative effect on completeness of immunization. Perceived susceptibility $(b=1.1 ; 95 \% \mathrm{CI}=0.2$ to $2.0 ; \mathrm{p}=0.022)$, perceived severity $(\mathrm{b}=1.5 ; 95 \% \mathrm{CI}=$ 0.5 to $2.5 ; \mathrm{p}=0.003)$, perceived benefit $(\mathrm{b}=0.7 ; 95 \% \mathrm{CI}=-0.1$ to $1.6 ; \mathrm{p}=0.110)$, and self efficacy $(\mathrm{b}=$ $0.6 ; 95 \% \mathrm{CI}=-0.3$ to $1.5 ; \mathrm{p}=0.193$ ) had a positive effect on completeness of immunization. Perceived susceptibility was affected by maternal education $(b=1.0 ; 95 \% \mathrm{CI}=0.3$ to $1.7 ; \mathrm{p}=0.005)$. Perceived severity was affected by maternal education $(\mathrm{b}=0.9 ; 95 \% \mathrm{CI}=0.5$ to $1.6 ; \mathrm{p}=0.018)$ and attitude towards immunization $(\mathrm{b}=1.0 ; 95 \% \mathrm{CI}=0.3$ to $1.8 ; \mathrm{p}=0.007)$. Perceived benefit was affected by family support $(b=0.7 ; 95 \% \mathrm{CI}=-0.1$ to $1.4 ; \mathrm{p}=0.078)$. Likeliwise, self efficacy was affected by family support $(\mathrm{b}=0.6 ; 95 \% \mathrm{CI}=0.1$ to $1.3 ; \mathrm{p}=0.134)$.

Conclusion: Perceived barrier and distance to health service have a negative effect on completeness of immunization. Perceived susceptibility, perceived severity, perceived benefit, and self efficacy have a positive effect on completeness of immunization.
\end{abstract}

Keywords: completeness of immunization, PRECEDE and PROCEED model, health belief model

\section{Correspondence:}

Nur Jayanti. Masters Program in Public Health, Universitas Sebelas Maret. Jl. Ir. Sutami 36 A, Surakarta 57126, Central Java. Email: Yanti_nurjayanti13@yahoo.co.id.

Mobile: +6282233829768.

\section{BACKGROUND}

An estimated of 1.5 million children under five in Indonesia are not yet covered by complete basic immunization programs or other vaccines. The complete basic immunization coverage rate in Indonesia is quite high, but in some regions, there are still below standard coverage rates (Kementerian Kesehatan RI, 2011).

Immunization can prevent approximately 25 million under-five deaths each year due to pertussis (whooping cough), tetanus, diphtheria, measles and hepatitis B. Not only that, immunization is also one 
of the most successful and cost-effective efforts for public health intervention (the cost light), especially for developing countries. Worldwide, polio immunization coverage in infants with 3 doses of polio vaccine in 2007 was $82 \%$ and Hepatitis B immunization coverage with 3 doses of vaccine was $65 \%$. DPT immunization coverage is $81 \%$ and measles $82 \%$ (WHO, 2009).

Indonesia has achieved Universal Child Immunization (UCI), but Indonesia still ranks 4th in the Under-vaccination Children in immunization coverage. This has resulted in Indonesia being one of the priority countries identified by WHO and United Nations Children's Fund (UNICEF) to carry out acceleration in achieving the target of 100\% UCI Village (WHO, 2011).

It is estimated that around 1,5 million children under five in Indonesia are not yet covered with complete basic immunization programs or other vaccines (Kementerian Kesehatan RI, 2011). Pamekasan Regency is one of the regencies in East Java which shows the low coverage of immunization acquisition (Dinkes Pamekasan, 2015).

The low immunization coverage in Pamekasan regency is due to various factors, namely the difficulty of accessing the public to get health services. This is because the place of health service that is far from the place of residence and difficult to reach, the level of education is lacking resulting in low public knowledge about the importance of immunization so that there is still rejection from the community regarding immunization, as well as the influence of socio-economic conditions of the local community (Dinkes Pamekasan, 2014 ).

According to Green and Kreuter (2004), health behavior is influenced by individual factors and environmental factors with the PRECEDE-PROCEED behavior change model. And there are three factors that can influence health service utilization behavior, namely: predisposing factors (education, attitudes, values, and beliefs), enabling factors include (distance to health services, limited facilities), and reinforcing factors (reinforcing factor) includes (family support and self-efficacy).

According to Rosenstock et al., the Health Belief Model (HBM) mentions that behavior is influenced by background, perception and trigger of action. The intended background is socio-demographic factors (education, age, gender, race, ethnicity, ethnicity). The perception includes threats and expectations. Threats consist of perceived vulnerabilities (receiving a diagnosis) and perceived severity of illness. Expectation includes the perceived benefit, perceived barrier, and self-efficacy to take action. Meanwhile, thickeners include media, individual influences, and reminder.

Based on the description above, the author was interested in examining the influence of predisposing, enabling, reinforcing, threat, and expectation factors on complete basic immunization acquisition behavior in Pamekasan Madura District using the PRECEDE-PROCEED model and Health Belief Model (HBM) theory with path analysis, to find out direct and indirect effects of a risk factor on the behavior of obtaining complete basic immunization in Pamekasan, Madura.

\section{SUBJECTS AND METHOD \\ 1. Study Design \\ This was an analytic observational study with a case control design. The study was conducted at Pasean, Batumarmar, Waru, and Pakong community health centers, Pamekasan, Madura, from March to April 2017.}

\section{Population and Samples}

The population in this study were mothers who have infants aged 10-12 months. The subjects of this study were mothers who 
had infant children aged 10 to 12 months living in 4 Pamekasan district community health centers and were selected as subjects according to the inclusion criteria. The inclusion criteria of this study were mothers of babies who were willing to become subjects in this study and have KIA book (Maternal Child and Health book) and KMS (a card to record toddler growth). A sample of 135 children was selected by fixed disease sampling consisting of 90 children with complete immunization and 45 children with incomplete immunization.

\section{Study Variables}

The dependent variable was completeness of immunization. The independent variables were education, attitude, distance to health service, family support, perceived vulnerability, severity, benefits, barrier, and self-efficacy.

\section{Operational Definition of Variables} The operational definition of immunization acquisition behavior was the acquisition of basic immunization services at the nearest health care facility.

Maternal education was the last formal education the mother has ever taken. Attitude was a positive or negative assessment from the mother about the immunization that will affect the mother to immunize her baby. The distance to health services defined as the distance between the residence of the study subject and the Table 1. Reliability Test Results

\begin{tabular}{lcc}
\hline \multicolumn{1}{c}{ Variables } & Total Item Correlation (r) & Cronbach's alpha \\
\hline Family Support & $\geq 0.28$ & 0.87 \\
Vulnerability & $\geq 0.35$ & 0.92 \\
Severity & $\geq 0.35$ & 0.71 \\
Advantages & $\geq 0.30$ & 0.78 \\
Obstacles & $\geq 0.43$ & 0.86 \\
Self-Efficacy & $\geq 0.58$ & 0.91 \\
Attitude & $\geq 0.50$ & 0.94 \\
\hline
\end{tabular}

nearest health service. Family support were various forms of support or assistance provided by family members in immunizing infants. Perceived of susceptibility were maternal perception of the level of risk and the impact of disease that will be experience if it is not immunized. Perceived severity defined as maternal view of the severity of the disease.

Perceived benefit was defined as benefits obtained between costs incurred with the level of illness experienced. Perceived benefit was defined as something that prevents a mother to immunize his baby. Selfefficacy was defined as a trust or confidence in your own ability to immunize your baby.

\section{Study Instrument}

The data were collected by questionnaire. Questionnaire was tested by reliability test using Cronbach's alpha. The results of reliability test were showed in Table 1 .

\section{Data Analysis}

The data were analyzed using path analysis with AMOS 20. Data analysis phase used AMOS path analysis, namely:
1. Model specification
2. Model Identification
3. Estimation
4. Fit Model
5. Model re-specification 
Journal of Epidemiology and Public Health (2017), 2(2): 107-119

https://doi.org/10.26911/jepublichealth.2017.02.02.02

\section{RESULTS}

\section{A. Univariate Analysis}

The study was conducted in 4 Pamekasan Community Health Center. The number of each sub-district is 11 and 12 mothers of babies who have incomplete immunization status and 23 and 22 mothers of babies who have complete immunization status.

Table 2 shows that the age proportion of the research subjects who had the highest complete immunization status at the age of 22 to 27 years was 30 people (33.3\%) and the highest proportion of the age of the research subjects who had incomplete immunization status at the age of 22 to 27 years was 19 people (42.2\%). While the proportion of the age of the husband of the research subject who had the highest complete immunization status at the age of 28 to 33 years was 37 people (41\%) and the proportion of the age of the husband of the research subject who had the highest incomplete immunization status at the age of 28-33 years was 16 people (36\%).

Table 2. Characteristics of Study Subjects

\begin{tabular}{|c|c|c|c|c|c|c|c|}
\hline \multirow{3}{*}{ Characteristics } & \multirow{3}{*}{ Category } & \multicolumn{4}{|c|}{ Immunization status } & \multirow{2}{*}{\multicolumn{2}{|c|}{ Total }} \\
\hline & & \multicolumn{2}{|c|}{ Complete } & \multicolumn{2}{|c|}{ Incomplete } & & \\
\hline & & $\mathbf{n}=\mathbf{9 0}$ & $\%$ & $n=45$ & $\%$ & $n=135$ & $\%$ \\
\hline \multirow[t]{4}{*}{ Maternal age } & 16 to 21 years & 23 & 25.5 & 10 & 22.2 & 33 & 25.0 \\
\hline & 22 to 27 years & 30 & $33 \cdot 3$ & 19 & 42.2 & 49 & 36.0 \\
\hline & 28 to 33 years & 29 & 32.2 & 13 & 29.0 & 42 & 31.0 \\
\hline & 34 to 39 years & 8 & 9.0 & 3 & 6.6 & 11 & 8.0 \\
\hline \multirow[t]{4}{*}{ Paternal age } & 22 to 27 years & 32 & 35.0 & 9 & 20.0 & 41 & 30.0 \\
\hline & 28 to 33 years & 37 & 41.0 & 16 & 36.0 & 53 & 40.0 \\
\hline & 34 to 39 years & 15 & 17.0 & 15 & 33.0 & 30 & 22.0 \\
\hline & 40 to 45 years & 6 & 7.0 & 5 & 11.0 & 11 & 8.0 \\
\hline \multirow{5}{*}{$\begin{array}{l}\text { Maternal } \\
\text { occupation }\end{array}$} & Housewife & 45 & 50.0 & 27 & 60.0 & 72 & 53.0 \\
\hline & Entrepreneur & 24 & 27.0 & 6 & 13.0 & 30 & 22.0 \\
\hline & Civil servant & 12 & 13.0 & 6 & 13.0 & 18 & 14.0 \\
\hline & Private & 6 & 7.0 & 3 & 7.0 & 9 & 7.0 \\
\hline & etc & 3 & 3.0 & 3 & 7.0 & 6 & 4.0 \\
\hline \multirow{5}{*}{$\begin{array}{l}\text { Paternal } \\
\text { Occupation }\end{array}$} & Enterpreneur & 21 & 23.0 & 4 & 9.0 & 26 & 19.0 \\
\hline & Civil servant & 8 & 9.0 & 1 & 2.0 & 9 & 7.0 \\
\hline & Private & 18 & 20.0 & 12 & 27.0 & 30 & 22.0 \\
\hline & Sailor & 36 & 40.0 & 25 & 55.0 & 61 & 45.0 \\
\hline & etc & 7 & 8.0 & 3 & 7.0 & 10 & 7.0 \\
\hline \multirow{2}{*}{ Family Income } & $\geq \operatorname{Rp} 1,350,000$ & 52 & 58.0 & 9 & 20.0 & 61 & 45.0 \\
\hline & $<\operatorname{Rp} 1,350000$ & 38 & 42.0 & 36 & 80.0 & 74 & 55.0 \\
\hline
\end{tabular}

The level of work of parents (father and mother) of babies were divided into six categories consisting of not working/housewives, entrepreneurs, civil servants, private employees, fishermen, and others. The type of work of parents of infants with complete immunization status had fathers who work- ed as fishermen for about 36 people (40\%) and mothers who did not work/ housewives were about 45 people (50\%). While the type of work of parents with incomplete immunization status had a father who worked as a fisherman for about 25 people (55\%) and mothers who did not work/housewives for 
about 27 people (60\%). Family income was divided into two categories Rp1,350,000 and $<\operatorname{Rp} 1,350,000$. Table 2 above shows that the proportion of family income with complete immunization status on income Rp1,350,000 were 52 people (58\%) and income $<$ Rp 1,350,000 with complete immunization status for about 38 people (42\%).

\section{B. Bivariate Analysis}

Table 3 shows the influence between education level, vulnerability, severity, benefits, obstacles, attitudes, self-efficacy, distance to health services, and family support with immunization acquisition behavior in $\mathrm{Pa}$ mekasan Madura district.

About $73.2 \%$ of parents with educational background $\geq$ high school have complete immunization status while $43.4 \%$ of parents with < high school have an incomplete immunization status. The results of the analysis with Chi Square test showed that there was a significant relationship between the level of education with immunization acquisition behavior $(\mathrm{OR}=2.0$; 95\% $\mathrm{CI}=1.0$ to $4.3 ; \mathrm{p}<0.001)$.

Approximately $82.3 \%$ of mothers with high vulnerability perception had complete the immunization status while $58.3 \%$ of mothers with low vulnerability perception had incomplete immunization status. The results of the analysis with Chi Square test showed a significant relationship between perceptions of vulnerability and immunization acquisition behavior with and $(\mathrm{OR}=$ 5.7; 95\% $\mathrm{CI}=2.6$ to $12.5 ; \mathrm{p}<0.001)$.

In the perception of severity variable, around $86.7 \%$ of mothers with high severity perception had complete immunization status while $58.3 \%$ of mothers with low severity perception had incomplete immunization status. The results of the analysis with Chi Square test showed that there was a significant relationship between the perception of severity with the acquisition behavior of immunization $(\mathrm{OR}=9.1 ; 95 \%$
$\mathrm{CI}=3.9$ to $21.0 ; \mathrm{p}<0.001)$. There are $76.7 \%$ benefits who had complete immunization status while $51.0 \%$ of mothers with a perception of small benefits had incomplete immunization status. The results of the analysis with Chi Square test showed that there was a significant relationship between perceived benefits with immunization acquisition behavior $(\mathrm{OR}=3.4 ; 95 \% \mathrm{CI}=1.6$ to 7.2 ; $\mathrm{p}<0.001)$.

About $61.7 \%$ of mothers with a large obstacle perception had a complete immunization status while $25.9 \%$ of mothers with a small obstacle perception had incomplete immunization status. The results of the analysis with Chi Square test showed that there was a significant relationship between obstacle perception and immunization acquisition behavior $(\mathrm{OR}=0.5 ; 95 \% \mathrm{CI}=0.2$ to $1.2 ; \mathrm{p}<0.001$ ).

About $76.1 \%$ of mothers with positive attitudes had complete immunization status while $51.1 \%$ of mothers with negative attitudes had incomplete immunization status. The results of the analysis with Chi Square test showed a significant relationship between attitudes with acquisition of immunization behaviors ( $\mathrm{OR}=3.3$; 95\% $\mathrm{CI}=1.5$ to $7.0 ; \mathrm{p}<0.001$ ).

About $71.4 \%$ of mothers with high self-efficacy have complete immunization status while $41.2 \%$ of mothers with low selfefficacy have incomplete immunization status. The results of the analysis with Chi Square test showed a significant relationship between self-efficacy and immunization acquisition behavior $(\mathrm{OR}=1.7 ; 95 \%$ $\mathrm{CI}=0.8$ to 3.6 ; $\mathrm{p}<0.001$ ).

Approximately $79.0 \%$ of mothers with a distance to health services $<3 \mathrm{~km}$ have complete immunization status while $43.8 \%$ of mothers with a distance to health services $\geq 3 \mathrm{~km}$ have incomplete immunization status. The results of the analysis with Chi Square test showed a significant relation- 
ship between distance to health services with immunization acquisition behavior (O$\mathrm{R}=0.3 ; 95 \% \mathrm{CI}=0.1$ to $0.7 ; \mathrm{p}<0.001$ ).

About $80.0 \%$ of mothers with strong family support have complete immunization status while $60.0 \%$ of mothers with weak family support have incomplete immunization status.

Table 3. The Results of Bivariate Analysis of the Dependent Variable on Obtaining Complete Basic Immunization Behavior in Pamekasan Regency, Madura

\begin{tabular}{|c|c|c|c|c|c|c|c|c|c|}
\hline \multirow{3}{*}{ Variable } & \multicolumn{4}{|c|}{ Immunization Status } & \multirow{2}{*}{\multicolumn{2}{|c|}{ Total }} & \multirow{3}{*}{ OR } & \multirow{3}{*}{$95 \% \mathrm{CI}$} & \multirow{3}{*}{$\mathbf{p}$} \\
\hline & \multicolumn{2}{|c|}{ Complete } & \multicolumn{2}{|c|}{ Incomplete } & & & & & \\
\hline & $\mathbf{n}$ & $\%$ & $\mathbf{n}$ & $\%$ & $\mathbf{n}$ & $\%$ & & & \\
\hline \multicolumn{10}{|c|}{ Educational Level } \\
\hline$<$ High School & 30 & 56.6 & 23 & 43.4 & 53 & 100 & \multirow[t]{2}{*}{2.0} & \multirow[t]{2}{*}{1.0 to 4.3} & \multirow[t]{2}{*}{$<0.001$} \\
\hline$\geq$ High School & 60 & 73.2 & 22 & 26.6 & 82 & 100 & & & \\
\hline \multicolumn{10}{|l|}{ Susceptibility } \\
\hline Low & 25 & 44.6 & 31 & $55 \cdot 4$ & 56 & 100 & \multirow[t]{2}{*}{$5 \cdot 7$} & \multirow[t]{2}{*}{2.6 to 12.5} & \multirow[t]{2}{*}{$<0.001$} \\
\hline High & 65 & 82.3 & 14 & $17 . .7$ & 79 & 100 & & & \\
\hline \multicolumn{10}{|l|}{ Severity } \\
\hline Low & 25 & 41,7 & 35 & 58,3 & 60 & 100 & \multirow[t]{2}{*}{9.1} & \multirow[t]{2}{*}{3.9 to 21.0} & \multirow[t]{2}{*}{$<0.001$} \\
\hline High & 65 & 86.7 & 10 & 13.3 & 75 & 100 & & & \\
\hline \multicolumn{10}{|l|}{ Benefit } \\
\hline Small & 24 & 49.0 & 25 & 51.0 & 49 & 100 & \multirow[t]{2}{*}{3.4} & \multirow[t]{2}{*}{1.6 to 7.2} & \multirow[t]{2}{*}{$<0.001$} \\
\hline Great & 66 & 76.7 & 20 & 23.3 & 86 & 100 & & & \\
\hline \multicolumn{10}{|l|}{ Barrier } \\
\hline Small & 40 & 74.1 & 14 & 25.9 & 54 & 100 & \multirow[t]{2}{*}{0.5} & \multirow[t]{2}{*}{0.2 to 1.2} & \multirow[t]{2}{*}{$<0.001$} \\
\hline Great & 50 & 61.7 & 31 & 38.3 & 81 & 100 & & & \\
\hline \multicolumn{10}{|l|}{ Attitude } \\
\hline Negative & 23 & 48.9 & 24 & 51.1 & 47 & 100 & $3 \cdot 3$ & 1.5 to 7.0 & $<0.001$ \\
\hline Positive & 67 & 76.1 & 21 & 23.9 & 88 & 100 & & & \\
\hline Self Efficacy & & & & & & & & & \\
\hline Low & 30 & 58.8 & 21 & 41.2 & 51 & 100 & 1.7 & 0.8 to 3.6 & $<0.001$ \\
\hline High & 60 & 71.4 & 24 & 28.6 & 84 & 100 & & & \\
\hline Distance to & & & & & & & & & \\
\hline Health Servic & & & & & & & & & \\
\hline$<3 \mathrm{~km}$ & 49 & 79.0 & 13 & 21.0 & 62 & 100 & 0.3 & 0.1 to 0.7 & $<0.001$ \\
\hline$\geq 3 \mathrm{~km}$ & 41 & 56.2 & 32 & 43.8 & 73 & 100 & & & \\
\hline Family Suppo & & & & & & & & & \\
\hline Weak & 18 & 40.0 & 27 & 60.0 & 45 & 100 & 60.0 & 2.7 to 13.2 & $<0.001$ \\
\hline Strong & 72 & 80.0 & 18 & 20.0 & 90 & 100 & & & \\
\hline
\end{tabular}




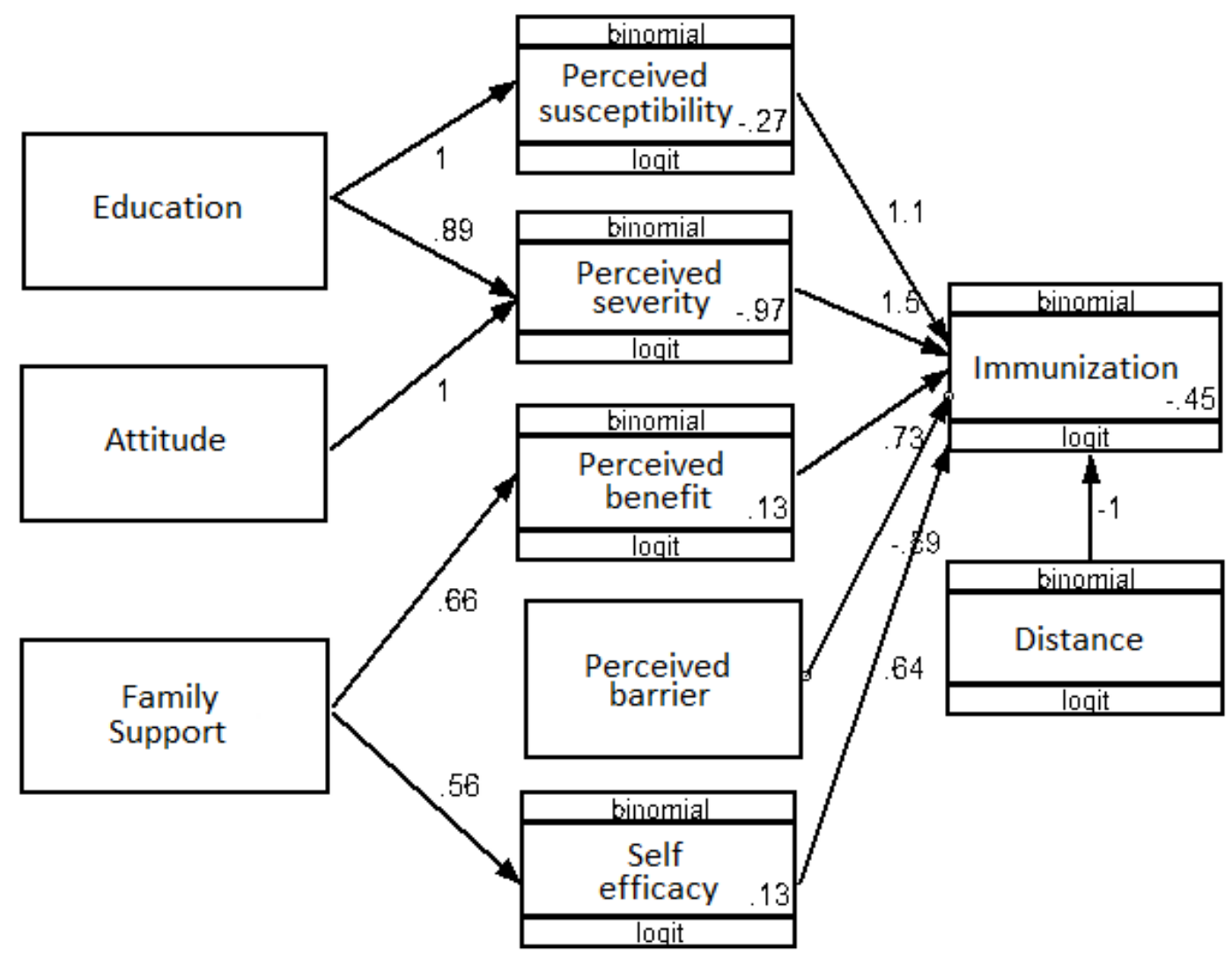

Figure 1. Structural Model with Estimation

Table 4. Path Analysis Results of the Effect of Educational Level, Susceptibility, Severity, Benefit, Barrier, Attitude, Self Efficacy, Distance to Health Services, and Family Support on the Complete Basic Immunization Behavior

\begin{tabular}{|c|c|c|c|c|c|c|}
\hline \multirow{2}{*}{$\begin{array}{c}\text { Dependent } \\
\text { Variable }\end{array}$} & & \multirow{2}{*}{$\begin{array}{l}\text { Independent } \\
\text { Variable }\end{array}$} & \multirow{2}{*}{$\begin{array}{c}\text { Path } \\
\text { Coefficient } \\
\text { (b) }\end{array}$} & \multicolumn{2}{|c|}{ 95\% CI } & \multirow[b]{2}{*}{$\mathbf{p}$} \\
\hline & & & & $\begin{array}{l}\text { Lower } \\
\text { Limit }\end{array}$ & $\begin{array}{l}\text { Upper } \\
\text { Limit }\end{array}$ & \\
\hline Immunization & $\leftarrow$ & Distance & -1.0 & -2.0 & -0.1 & 0.037 \\
\hline Immunization & $\leftarrow$ & Susceptibility & 1.1 & 0.2 & 2.0 & 0.022 \\
\hline Immunization & $\leftarrow$ & Severity & 1.5 & 0.5 & 2.5 & 0.003 \\
\hline Immunization & $\leftarrow$ & Benefit & 0.7 & -0.1 & 1.6 & 0.110 \\
\hline Immunization & $\leftarrow$ & Barrier & -0.5 & -1.5 & 0.4 & 0.255 \\
\hline Immunization & $\leftarrow$ & Efficacy & 0.6 & -0.3 & 1.5 & 0.193 \\
\hline Susceptibility & $\leftarrow$ & Education & 1.0 & 0.3 & 1.7 & 0.005 \\
\hline Severity & $\leftarrow$ & Education & 0.9 & 0.5 & 1.6 & 0.018 \\
\hline Severity & $\leftarrow$ & Attitude & 1.0 & 0.3 & 1.8 & 0.007 \\
\hline Benefit & $\leftarrow$ & Family Support & 0.7 & -0.1 & 1.4 & 0.078 \\
\hline Efficacy & $\leftarrow$ & Family Support & 0.6 & -0.1 & 1.3 & 0.134 \\
\hline
\end{tabular}

\section{Path Analysis}

Table 4 showed that there was an effect of the distance to health services on immunization behavior and the result was statis- tically nearly significant. Mothers with the distance to health services of $\geq 3 \mathrm{~km}$ decrease the completeness of basic immunization with the $\log$ odd of 1.0 times smaller than 
the mothers with the distance to health services of $<3 \mathrm{~km}(\mathrm{~b}=-1.0 ; 95 \% \mathrm{CI}=-2.0$ to $0.1 ; \mathrm{p}=0.037$ ).

There was an effect of perceived susceptibility of diseases on the complete basic immunization and the result was statistically nearly significant. Mothers with low perceived susceptibility have a 1.1 times greater log odd to immunize their baby than mothers who have high perceived susceptibility (95\% CI= 0.2 to $2.0 ; \mathrm{p}=0.022)$.

There was an effect of perceived severity of the disease on the completeness of basic immunization behavior and the result was statistically nearly significant. Mothers with low perceived severity have 1.5 times greater log odd to immunize their babies than mothers who have high perceived severity ( $95 \% \mathrm{CI}=0.5$ to $2.5 ; \mathrm{p}=$ 0.003).

There was an effect of perceived benefit on the complete basic immunization behavior and the result was statistically nearly significant. Mothers with small perceived benefit have a 0.7 time greater logodd to immunize their babies than mothers who have great perceived benefit (95\% $\mathrm{CI}=-0.1$ to $1.6 ; \mathrm{p}=0.110)$.

There was a negative effect of perceived barrier on complete basic immunization behavior and the result was statistically nearly significant. The effect was negative because mothers with great perceived barrier decrease the completeness of immunization with -0.5 times smaller log odd than mothers who have small perceived barrier ( $95 \% \mathrm{CI}=-1.5$ to $0.4 ; \mathrm{p}=0.255$ ).

There was an effect of self efficacy on the complete basic immunization behavior and the result was statistically nearly significant. Mothers with low self efficacy have o.6 time greater log odd to immunize their babies than mothers with high self efficacy (95\% $\mathrm{CI}=-0.3$ to $1.5 ; \mathrm{p}=0.193$ ).
There was an effect of maternal education on perceived susceptibility and the result was statistically significant.Mothers who were <High School have 1.0 times greater log odd to immunize their babies than mothers who were $\geq$ High School $(95 \%$ $\mathrm{CI}=0.3$ to $1 . ; \mathrm{p}=0.005$ ).

There was an effect of maternal education on perceived severity of the diseases and the result was statistically significant. Mothers who were $<$ High School have 0.9 time greater log odd to immunize their babies than mothers who were $\geq$ High School (95\% $\mathrm{CI}=0.1$ to $1.6 ; \mathrm{p}=0.018$ ).

There was an effect of maternal attitudes on perceived severity of the diseases and the result was statistically significant. Mothers with negative attitudes have 1.0 time greater log odd to immunize their babies than mothers who have positive attitudes ( $95 \% \mathrm{CI}=0.3$ to $1.8 ; \mathrm{p}=0.007)$.

There was an effect of family support on perceived benefit and the result was statistically significant. Mothers with lack of family support have 0.7 times greater logodd to immunize their babies than mothers who have strong family supports $(95 \%$ $\mathrm{CI}=-0.1$ to $1.4 ; \mathrm{p}=0.078$ ).

There was an effect of family support on self efficacy and the result was statistically nearly significant. Mothers with lack of family support have 0.6 times greater log odd to immunize their babies than mothers who have strong family supports $(95 \% \mathrm{CI}=$ -0.1 to $1.3 ; \mathrm{p}=0.134$ ).

\section{DISCUSSIONS}

\section{The Effect of Distance to Health Services on Complete Basic Immu- nization Behavior}

The result of this study showed that there was an effect of distance to health services on complete basic immunization behavior. According to Green et al., (1978) supporting factors were factors that enable a 
motivation to behave healthily, and these factors include resources in the community in the form of physical environment, the availability of health facilities such as distance.

The distance in this case was about how far the mother's residence was to the place of health services. The further the distance to health services, the lower the utilization of health services. The result of this study was in line with a study done by Idwar (2001) which stated that there was a meaningful relationship between immunization status with close distance compared to a far distance by 1.01 times.

\section{The Effect of Perceived Suscep- tibility of Diseases on Complete Basic Immunization Behavior}

The result of this study showed that there was an effect of perceived susceptibility on complete basic immunization behavior. This study was supported by a study of Smith et al., (2011) which showed that the actions of parents who deliberately refuse to give vaccination to their children were less likely to believe that vaccination was needed to protect the health of their children compared to parents who give vaccinations to their children.

According to Rosenstok (1982) in Noorkasiani (2009), people who felt that they can be affected by the disease would feel threatened more quickly. And this threat can encourage every individual to take action to prevent or cure the diseases compared to people who did not feel affected by the disease.

Meanwhile, according Hayden (2010), if there was someone who felt that she/he would be at risk of developing a disease, then she/he would do something that she/he thought was safe and took immediate precautions.

\section{The Effect of Perceived Severity of Diseases on Complete Basic Immu- nization Behavior}

The result of this study showed an effect of perceived severity of diseases on complete basic immunization behavior. The results of this study supported several theories about Health Belief Model (HMB) which stated that someone who felt the severity would determine whether there was a preventive action that would be taken for the disease or not (Hayden, 2010).

Priyoto (2014) also stated that perceived severity was often based on knowledge or medical information, which can also came from a person's belief that he/she would get difficulties from the diseases. Someone who felt that if the disease that can be prevented by immunization was a severe disease, then that person would feel threatened. And the threat would encourage individuals to take prevention (Rosenstok, 1982 in Noorkasiani, 2009). The perceived severity of the individuals would determine whether there was a prevention that they could do for the disease or not.

\section{The Effect of Perceived Benefit on Complete Basic Immunization Behavior}

The result of this study showed that there was an effect of perceived benefit on complete basic immunization behavior. The result of this study was supported by a study of Smith et al., (2011) which revealed that parents who disagree to vaccinate their children would feel less benefit of the vaccine. Whereas parents who agreed with the vaccine consider that giving vaccinations to their children was beneficial to the health of their children.

The perceived benefit was the opinion of someone about the value of a new behavior in reducing the risk of disease. Individuals would tend to implement 
Journal of Epidemiology and Public Health (2017), 2(2): 107-119

https://doi.org/10.26911/jepublichealth.2017.02.02.02

healthy behavior when they felt that the behavior was beneficial for reducing a disease. Immunization in infants was not only to take an effort to prevent the diseases, but it actually can prevent the diseases. Therefore, the attitudes and knowledge about the benefits of immunization were needed.

In this study, it showed that individuals would take preventive action which in this case was vaccination if the individual felt that the action was beneficial. There were some individuals who did not immunize their babies because they still did not feel the benefits of that prevention.

\section{The Effect of Perceived Barrier on Complete Basic Immunization Behavior}

The result of this study showed that there was an effect of perceived barrier of diseases on complete basic immunization behavior. Perceived barrier was a barrier felt by individuals in taking a decision to immunize their babies. The perceived barriers in this case was related to the barriers faced by individuals to adopt new behaviors.

According to Priyoto (2014), perceived barrier was a significant element in determining whether there was a change in behavior or not. Related to the new behavior that would be adopted, individuals must believe that the benefits of the behavior must be greater than continuing the old behavior.

Someone who would perform a health action would find many barriers, and these barriers came because the individual evaluated the barriers on new behavior. Before adopting an action, individuals must believe that the number of the barriers in taking preventions was smaller than the consequences of that action.

\section{The Effect of Self Efficacy on Complete Basic Immunization Behavior}

The result of this study showed that there was an effect of self efficacy on complete basic immunization behavior. Self-efficacy was the belief in someone's own ability to do something (Sulaeman (2016). Selfefficacy was also one of knowledge aspects about self-knowledge which was most influential in everyday life because selfefficacy has affected the individual in determining the actions to be taken to achieve a goal, including an estimate of the challenges that would be faced. Judge et al, also stated that self-efficacy was a positive indicator of core self evaluation for selfevaluation that was useful for understanding ourselves (Judge et al, 2001).

This self-efficacy refer to the individual's perception or competence to successfully conduct a behavior. Based on a study done by Waluyanti (2009), it showed that mothers who have high and low selfefficacy showed the incompleteness in immunization. This showed that there was no relationship between self-efficacy and immunization compliance.

\section{The Effect of Maternal Education on Perceived Susceptibility}

The result of this study showed that there was an effect of educational level on complete basic immunization behavior through perceived susceptibility. The basic concept of education was a learning process which mean the changes that lead to more mature ones. Education was a very important thing in influencing the knowledge. Someone who has a high level of education tend to be more receptive to information which in this case was information about immunization, whereas individuals with low levels of education would have difficulty in receiving information so that they were less aware of 
the completeness of immunization (Rahmawati, 2013).

The level of education that has been obtained by an individual from formal school could affect his/her knowledge. Existing health education would be able to help mothers to improve their knowledge as well as to improve their behavior to achieve a better level of health. The level of maternal formal or non-formal education was highly affected the implementation of each immunization activity for infants (Rahmawati, 2013).

Mothers who have a high level of education would have a perceived susceptibility due to a severe disease, so that the mother would be more quickly to take an action to prevent a disease.

\section{The Effect of Maternal Education} on Complete Basic Immunization Behavior through Perceived Severity

The result of this study showed that there was an effect of maternal education on complete basic immunization behavior through perceived severity. The result of this study was in line with a study done by Isfan (2006) which stated that mothers with low level of education were 2.01 times more likely to have the incompleteness of basic immunization in children than highlyeducated mothers.

If a preventive intervention program such as immunization need to be carried out seriously in answering the changes in disease patterns, then the improvements in public health behavior evaluation and increased knowledge were needed (Prasetyo, 2009).

Therefore, it can be concluded that education was highly necessary for someone to give the ability to think, learn, and understand the information obtained by considering it with more rational things. Good education can also give a good ability to people in making decisions about health to their families, especially in giving immunizations to their children.

9. The Effect of Maternal Attitude on Complete Basic Immunization Behavior, through Perceived Severity

The result of this study showed that there was an effect of maternal attitude on complete basic immunization behavior through perceived severity.

According to Newcomb in Soekidjo Notoatmodjo (2007), attitude was the readiness or willingness to act and it was not an implementation of certain motives. Attitude was not an action or activity, but it predisposed to an act of behavior. Attitude was an internal reaction of someone that can be influenced by various factors. The process of attitudes was due to stimulation such as community knowledge. This stimulation stimulated the community to respond in the form of positive attitudes and negative attitudes which would eventually be realized in the form of a real action (Azwar, 2013).

Negative attitudes that emerged from the community about immunization need to be improved so that the next generation can avoid the diseases that can be prevented by immunization. And the action that can be done was by conducting counseling to the community about the importance of immunization, side effects of immunization, and the content of immunization vaccines given to the infants. This was done to prevent the assumption that immunization was not important, and that the immunization was forbidden or prohibited.

10. The Effect of Family Support on Complete Basic Immunization Behavior, through Perceived Benefit

The result of this study showed that there was an effect of family support on complete basic immunization behavior through 
perceived benefit. This was in accordance with a study by Siswandoyo (2003) which stated that family support did not guarantee the completeness of immunization.

Someone need support to behave healthily. With the support from the surrounding environment, it would be easier for people to change their behaviors (Notoatmodjo, 2005). While a study conducted by Agus (2000) stated that there was a relationship between family support and maternal behavior in immunizing their children. Mothers who did not get family support were 2.6 times less likely to immunize their children.

\section{The Effect of Family Support on Complete Basic Immunization Be- havior, through Self Efficacy}

The result of this study showed that there was an effect of family support on complete basic immunization behavior through selfefficacy. Family is the smallest part of the community, which consisted of head of the family and family members. There was an interaction between family members with one another, if one of the family members got a health problem, then it could affect other family members. Therefore, family was the focus of strategic health services because family has a major role in maintaining the health for all family members (Mubarak, 2012)

Family support was one of the factors that affect maternal behavior in providing immunization to their babies. If the mothers did not get support from their family, it would be difficult for them to provide immunization for their babies. Family support also affected the individual's ability to immunize their babies.

\section{REFERENCES}

Azwar S (2013). Sikap Manusia Teori dan Pengukurannya. Edisi 2. Yogyakarta: Pustaka Pelajar.
Dinkes Pamekasan (2014). Buku Profil Kesehatan Kabupaten Pamekasan Tahun 2013. Dinas Kesehatan Pamekasan. (2015). Buku Profil Kesehatan Kabupaten Pamekasan Tahun 2014. Pamekasan.

Green LW, Kreuter MW (2004). Health Promotion Planning an Education and Environmental Approach ( $2^{\text {nd }}$ edition). Mayfield Publishing Company, London.

Idwar (2001). Faktor - faktor yang Berhubungan dengan Status Imunisasi Hepatitis B pada Bayi o-11 Bulan di Kabupaten Aceh Besar Provinsi Daerah Istimewa Aceh. Fakultas Kesehatan Masyarakat Universitas Indonesia. Jakarta.

Isfan, Reza (2006). Faktor - faktor yang Berhubungan dengan Status Imunisasi Hepatitis B pada Bayi (0-11 bulan) di Kabupaten Aceh Besar Provinsi Daerah Istimewa Aceh. Program Pascasarjana Fakultas Kesehatan Masyarakat Universitas Indonesia, Depok.

Hayden J (2010). Introduction to Health Behavior Theory. USA: Jones and Bartlett Publisher.

Kementerian Kesehatan RI (2011). Direktorat Surveilans Epidemiologi, Imunisasi, dan Kesehatan Matra, Direktorat Jendral Pengendalian Penyakit dan Penyehatan Lingkungan, Departemen Kesehatan Indonesia. Jakarta.

Noorkasiani, Heryati, Ismail (2009). Sosiologi Keperwatan. Jakarta: ECG.

Notoatmodjo (2005). Metode Penelitian Kesehatan. Jakarta: Rineka Cipta. (2007). Kesehatan Masyarakat: Ilmu dan Seni. Jakarta: Rineka Cipta.

Mubarak WI (2012). Ilmu Kesehatan Masyarakat Konsep dan Aplikasi Dalam Kebidanan. Jakarta: Salemba Medika. 
Priyoto (2014). Teori Sikap \& Perilaku dalam Kesehatan. Yogyakarta: Nuha Medika.

Rahmawati AI (2013). Faktor Yang Mempengaruhi Kelengkapan Imunisasi Dasar di Kelurahan Krembangan Utara. FKM Unair.

Siswandoyo, Putro G (2003). Beberapa Faktor yang Berhubungan dengan Status Kelengkapan Imunisasi Hepatitis B Pada Bayi di Puskesmas Lanjas Kabupaten Barito Utara, Kalimantan Tengan. Medika, No. 4; 251-257.

Smith PJ, Humistog SG, Marcuse SK, Zhao Z, Dorel CG, Howes C (2011). Parental Delay or Refusal Of Vaccine Doses Childhood Vaccination Coverage at 24 Months of Age, and The Health Belief Model. Public Health Rep. 2: 135-146.

Sulaeman SE (2016). Pembelajaran Model dan Teori Perilaku Kesehatan Konsep dan Aplikasi. Surakarta: UNS Press.
Waluyanti FT (2009). Analisis Faktor Kepatuhan Imunisasi di Kota Depok. Program Magister Ilmu Keperawatan Anak Program Studi Pascasarjana Fakultas Ilmu Keperawatan.

WHO (2009). Immunization Safety Surveillance: Guidelines for Managers of Immunization Programs on Reporting and Investigating Adverse Event Following Immunization. http://www.who.int/immunization safety/publications/aefi/en/AEFI_WPRO.p df. Accessed on 21 November 2016.

WHO (2011). Weekly Epidemilogical Report. http://www.who.int/wer/2011/wer8646.pdf. Accessed on 15 October 2016. 